\title{
Relationship Between Cultural Intelligence and Cross-Cultural Adjustment of Foreign Employees in Kosovo
}

\author{
Vjosë HAJRULLAHU (D) a Hasan TUTAR iD b Alban FEJZA (iD c \\ a Sakarya University, Sakarya, Turkey. vjose.hajrullahu@ogr.sakarya.edu.tr \\ b Bolu Abant Izzet Baysal University, Bolu, Turkey. hasantutar@ibu.edu.tr \\ c Heimerer College, Kosovo. albanfeiza@gmail.com
}

\begin{tabular}{|c|c|}
\hline ARTICLE INFO & ABSTRACT \\
\hline $\begin{array}{l}\text { Keywords: } \\
\text { Cross-Cultural } \\
\text { Adjustment } \\
\text { Cultural Intelligence } \\
\text { Foreign Employees }\end{array}$ & $\begin{array}{l}\text { Purpose - Cross-cultural adjustment is crucial for the success of employees in a different cultural } \\
\text { environment. Cultural intelligence is believed to be a skill that can enhance adjustment during cross-cultural } \\
\text { interactions. Cross-cultural adjustment is crucial for the success of employees in a different cultural } \\
\text { environment. This study aimed to determine the relationship between cross-cultural adjustment and } \\
\text { cultural intelligence by examining a sample of employees working in Kosovo with a foreign country of } \\
\text { origin. }\end{array}$ \\
\hline $\begin{array}{l}\text { Received } 5 \text { June } 2021 \\
\text { Revised } 8 \text { September } 2021 \\
\text { Accepted } 15 \text { September }\end{array}$ & $\begin{array}{l}\text { Design/methodology/approach - This study is quantitative in terms of its methodology. The empirical data } \\
\text { comes from a survey of foreign employees living in Kosovo and working in private businesses from thirteen } \\
\text { types (sectors) of institutions. }\end{array}$ \\
\hline Article Classification: & $\begin{array}{l}\text { Results - The study results show that dimensions of cultural adjustment are associated with dimensions of } \\
\text { cultural intelligence. Therefore, this study confirms the effect of cultural intelligence domains on the cross- } \\
\text { cultural adjustment of employees working in a foreign country. }\end{array}$ \\
\hline Research Article & $\begin{array}{l}\text { Discussion - In recognition of the importance of cross-cultural adjustment for foreign employee's } \\
\text { performance, we suggest organizations and employees invest in training and other efforts like visits to the } \\
\text { new duty country before starting work, increasing the cultural intelligence components of a person, and } \\
\text { enhancing cross-cultural adjustment. }\end{array}$ \\
\hline
\end{tabular}

\section{INTRODUCTION}

Cross-cultural adjustment is an ability that became crucial, especially with the whispered of globalization, a process that has brought people from different cultural backgrounds (Sotshangane 2005) together in one working medium. Working in multicultural settings means a greater need for effective international and crosscultural communication, collaboration, and cooperation (House, Hanges, Javidan, Dorfman, and Gupta 2004). Although the process of globalization is ubiquitous, the connection to other parts of the world does not negate the importance of considering the importance of cultural differences as a contributor to challenges and opportunities faced when working in multicultural environments. Cultural intelligence is a skill that facilitates the process of cross-cultural adjustment, as foreign workers face opportunities and challenges in the multicultural arena (Mosakowski and Earley 2004:139), and their adjustment ability provides workers with a kind of "comfort zone" when interacting with people from different cultural backgrounds.

An area where cross-cultural adjustment and cultural intelligence can have important implications is the migration of employees between countries. Many countries, including Kosovo, attract skilled workers to meet their demand for labor. In Kosovo, private businesses or firms have many difficulties with an inadequately educated and low-skilled workforce (Cojocaru 2017). The education system has not yet managed to equip students with the specific skills and the soft skills necessary to succeed in the changing labor market (Cojocaru 2017; Riinvest 2017). Finding employees with the required skills and competencies is significant for developing the private sector (Cojocaru 2017:.3). In finding employees with those necessary abilities that would allow them to thrive in worldwide business sectors, there are critical issues that Kosovo should consider, such as regionally harmonized university curricula and university programs with international recognition, and also 


\section{Hajrullahu - H. Tutar - A. Fejza 13/3 (2021) 2440-2454}

continuous professional development in line with international best practices (World Bank Group 2017). Encouraging regional and international economic integration by connecting to global markets through trade, transport, and investment (World Bank Group 2017), and benefiting from workforce mobility as cited in World Bank's paper (Handjiski et al. 2010) could bring very important experiences for Kosovarian businesses. Taking into consideration the importance of international best practices and their impact in businesses performance, we suggest that the presence of foreign employees in the country will always be an important topic and concern, and for them to perform better their cross-cultural adjustment will be crucial.

Previous studies have indicated the relationship between cultural intelligence and cross-cultural adjustment among students and expatriates in different countries such as the US (Gudmundsdottir, 2015), Japan (Huff et al. 2014a), Taiwan (Lin et al. 2012). Less work has been done to understand this relationship among foreign employees operating in emerging economies such as Kosovo, considering that the Kosovo business environment faces significant institutional barriers. Kosovo's economy remains one of the poorest in the region, and as a result, there are many barriers like weak protection of property rights and contractual enforcement, the failure of the privatization process, and the failure of building a suitable climate for the private sector (Kryeziu \& Coşkun 2018). This paper addresses this gap, using a sample of foreign workers employed in the private sector in Kosovo. Here the term "foreign employees" is used in the same way as in the study of Ravasi et al. (2015), where this term is used to name the 'internationally mobile individuals who moved from a foreign country to Kosovo for work-related reasons.

\section{THEORETICAL BACKGROUND AND HYPOTHESIS DEVELOPMENT}

\section{Cultural Intelligence}

Cultural intelligence, a recently emerging concept in explaining the ability that enhances people to interact better in culturally different environments, is considered the reason behind people's success in cross-cultural interactions. Among those cross-cultural interactions increasing due to globalization and European integration have caused a global labor movement worldwide. There are many challenges that people have to face in this regard, such as conflicts, tensions, and recognizing and appreciating cultural values (Polák-Weldon et al., 2012; House et al., 2004). Some potential explanations for these struggles and inabilities to adjust to living and working in a different culture are unawareness of the critical characteristics and biases within their own culture, feeling uncomfortable when interacting cross-culturally, and being unable to comprehend or clarify practices of others in those environments (Thomas and Inkson 2017). Furthermore, Livermore (2011) coined cultural intelligence, adding it as a new ability that was not covered by the previously existing intercultural models of Hall, Hofstede, Schwartz, and Trompenaars. This addressed multicultural interaction obstacles and the reason for their variation.

Mosakowski and Earley (2004:146) identified cultural intelligence (CQ) as separate from emotional or social intelligence. They argued that a person with high CQ, whether developed or inborn, could comprehend and master such situations, persevere, and behave appropriately in a specific context. According to Earley (2002:.283), the primary difference between cultural intelligence and other faceted intelligence models is the domain of interaction. Cultural intelligence reflects the capability of a person to adapt to multicultural environments, and, as cited by Polák-Weldon et al., (2012:359), is "the individual's ability not only to bridge the gap between people from different cultures cultural backgrounds but also to turn cultural pluralism into an asset," Cultural intelligence is positively related to a better cross-cultural competence which is very important in today's globalized world (Li 2020). Moreover, cultural intelligence has been proved to affect people's personalities by enhancing a more proactive personality, allowing them to adjust (Hu et al., 2019). It is, therefore, an essential skill in preventing challenges in culturally different environments.

To better understand the importance of cultural intelligence and its effect on intercultural harmony, it is necessary to look at the definition of culture. Knowing one's own culture and others' culture and understanding the function of culture, in general, is a crucial element for success when working in crosscultural environments. According to Hofstede, Hofstede, and Minkov (2010:6), culture can be understood as 


\section{Hajrullahu - H. Tutar - A. Fejza 13/3 (2021) 2440-2454}

the collective programming of the mind that distinguishes the members of one group or category of people from others. Cultures tell their members who they are, how to behave toward each other, and how to feel good about themselves (House et al. 2004:31). By this definition, culture is a guideline for a society, which addresses the ways that help society to accommodate the fundamental needs of its members, including universal needs of food, water, clothing, and understanding the distribution of those essential resources necessary for culturally intelligent leaders (Livermore 2015:73). A person who can understand that every culture has its norms and values, how those could differ from culture to culture, and understanding the impact these have on life and how work is done should better adjust to different cultures. If people could understand the jargon and subtle meanings of the other language, as well as how behaviors are interpreted as "good" or "bad" concerning cultural normals and etiquette, could lead them to be successful in a global arena where many cultures interact (House et al. 2004:87).

Cultural Intelligence is taken as a multidimensional intelligence constructed from cognitive $C Q$, metacognitive CQ, motivational CQ, and behavioral CQ (Livermore 2015, Van Dyne et al. 2012). The cognitive dimension of the CQ is constructed from general culture knowledge and specific knowledge dimensions and refers to the leader's knowledge about culture and its role in shaping the way business is done (Livermore 2015:26; Van Dyne et al. 2012:304).

Metacognitive CQ is the leader's ability to strategize in different cultural contexts (Livermore 2015:27). It is composed of planning, awareness, and checking dimensions. It is found that people with higher metacognitive CQ consciously question their cultural assumptions and the assumptions they have about culturally diverse others (Van Dyne et al., 2012:299-300). The motivational dimension of CQ is the leader's level of interest, drive, and energy directed toward effective functioning in intercultural settings and the energy to adapt cross-culturally (Livermore 2015:26; Van Dyne et al. 2012:304). It comprises three subdimensions: intrinsic interest, extrinsic interest, and self-efficacy to adjust. Behavioral CQ is the leader's ability to act appropriately in cross-cultural situations. The behavioral CQ subdimensions are verbal behavior, non-verbal behavior, and speech acts (Van Dyne et al., 2012:304). According to Livermore (2015:27-28), one of the most critical aspects of CQ action is knowing when to adapt to another culture and not doing so. A person with high CQ learns which actions will not enhance effectiveness and acts on that understanding.

\section{Cross-Cultural Adjustment}

Cross-cultural adjustment is the process of adapting to new conditions of life and work in a new culture. Previous researchers in the field of cross-cultural adjustment have described it as a process, and they attempted to explain it through Social Learning Theory (Bandura 1977; Black and Mendenhall 1991; Searle 1990). As a learning process, social learning theory provides a theoretical framework within which crosscultural adjustment can be examined, given that adjusting to new cultures is considered a learning process (Black and Mendenhall 1991:245). In a new culture, the adjustment occurs through this learning process, whereby individuals respond to naturalize the obstacles encountered (Anderson 1994:302). According to the author, a person's adjustment is a process that comes from a motive and goal-directed movement directed to an obstacle, such as verbal or non-verbal communication and general and work conditions. The capability to overcome those obstacles comes from adjustment, which itself occurs as a response to them.

Cross-cultural adjustment or adaptation works successfully when team members are willing to acknowledge and name their cultural differences and to assume responsibility for figuring out how to live with them (Brett et al., 2009:90). Black and Mendenhall (1991:241) pointed out that the greater the level of attention paid by the expatriate to use country nationals as models of new, appropriate behavior, the sooner the expatriate will receive positive reinforcement and the quicker he or she will adjust to the host culture. At this point, cultural intelligence is considered very important as a skill that should enhance the acknowledgment of this new, appropriate behavior and expedite adjustment.

Adjustment is considered to be a multi-faceted construct. The facets of cross-cultural adjustment were first described in Black (1988), who tested the factors affecting American expatriates' adjustment working in Japan. The study pointed out that general adjustment included an adjustment to general living conditions, 


\section{Hajrullahu - H. Tutar - A. Fejza 13/3 (2021) 2440-2454}

transportation systems, food, shopping, weather, and entertainment and was termed general adjustment or adjustment to living conditions and everyday life; Interaction adjustment included interacting with people outside the company and interacting with people in general. The work adjustment dimension was also an adjustment to work responsibilities (Black 1988:283). In summary, cross-cultural adjustment is generally measured by experiencing the transition, adjusting to the general environment, the work situation, or interacting with host nationals (Black 1990:123).

\section{Cultural Intelligence and Cross-Cultural Adjustment: Hypothesis Development}

Cultural intelligence as the "capability to function effectively across national, ethnic, and organizational cultures" (Livermore 2015:4) facilitates understanding of the norms and practices of a culture, including culture-specific rules of emotion (Sharma and Hussain 2017:97). This enhances skills and the development of appropriate behaviors through interactions with other cultures (Thomas and Inkson 2009:16), which assists in adjusting one's behavior according to that culture's rules and effectively adapt to it. As Livermore (2015:73) pointed out, general awareness about the economic systems' organization will enhance the ability to develop working relationships in a culture different from the expatriate's own culture.

Understanding the cultural differences that affect people's attitudes and behaviors is essential for better intercultural cohesion. Findings from Abugre et al., (2020) study reveal that host country culture plays a significant role in determining expatriate adjustment in distant subsidiaries. There are many examples of how cultural differences affect behavior patterns. Some of them are avoiding uncertainty, formal relationships between persons, holding formal meetings instead of intimate relationships, using formal procedures for all kinds of actions, and confirming oral communications in writing. While most individuals in low uncertainty avoidance cultures tended to exhibit traits and practices like being more informal, relying on the word of others they trust rather than contractual arrangements; and being less concerned with orderliness and the maintenance of records (House et al. 2004; Andreatta and Ferraro 2012:39-40).

In Kosovo's case, the culture profile is characterized by a shift from collectivism to individualism, high power distance, and highlighted masculinity traits (Terziu 2016). These characteristics affect the way business is carried out. Such characteristics may explain foreign investors' challenges, such as physical infrastructure, bureaucratic procedures, political environment, corruption and nepotism, reforms in state administration, and the education system (Shkodra et al., 2015). Those characteristics and obstacles are essential for foreign employees to know when beginning to work in Kosovo. According to House et al. (2004:7), if people from different cultures are aware of their cultural differences, they will negotiate mutually agreeable approaches to conflict resolution, problem-solving, decision making, and management practices. One important finding that demonstrates the impact of differences in cross-cultural adjustment is that, according to Zhang (2013), the relationship between $C Q$ and adjustment was more potent when the direction of cultural flow was from a less authoritarian cultural context to a more authoritarian cultural context.

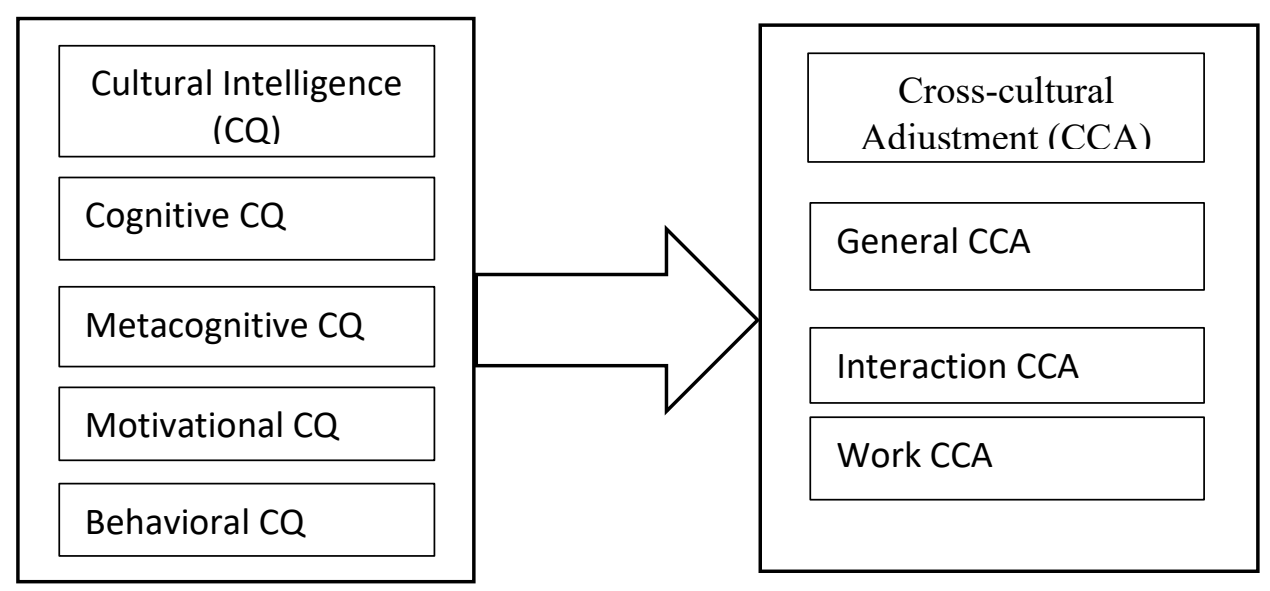

Fig 1. Illustrates the model and the hypothesis of this research 


\section{Hajrullahu - H. Tutar - A. Fejza 13/3 (2021) 2440-2454}

CQ is essential in affecting several important expatriate success indicators, including adjustment (Miller and Shaffer 2008:116). Individuals with a higher CQ level will be better adjusted to the new work and non-work environments in the host country because it is likely that individuals with higher CQ will gain more appropriate emotional and informational support through better interaction with local people (Kirkman and Chen 2006:1-3). In many studies, examining the relationship between cultural intelligence and cross-cultural adjustment of expatriates from different countries such as Brazil (Nunes et al. 2017) and with the expatriate managers of Taiwanese multinational company (MNC) subsidiaries operating in China (Lee et al. 2013), it was found that cultural intelligence had a significant effect on expatriate adjustment.

H1. There is a positive relationship between cultural intelligence and cross-cultural adjustment.

As the people's knowledge about culture's role in shaping how business is shaped, cognitive CQ (Livermore 2015) contributes to strategic thinking abilities ( $\mathrm{Wu}$ and Ang 2011), strengthening the ability to adjust crossculturally. Individuals who recognize the difference in culturally intelligent behavior between cultures will better understand what they must do to adjust effectively during overseas assignments (Brislin et al., 2006: 45). By raising the consciousness of the importance of adjusting, cultural intelligence enables employees to adjust to different cultures (Sternberg 2008, p.315).

H1a. There is a positive relationship between cognitive CQ and (a) general adjustment, (b) interaction adjustment, and (c) work adjustment.

Metacognitive CQ facilitates increased adjustment to new cultures (Guðmundsdóttir 2015) by enhancing employees' ability to strategize in different cultures and deal with people, places, and events. Considering this facet's characteristics, promoting active thinking about people and situations in culturally different environments (Dyne et al. 2008), we can conclude that metacognitive CQ will positively relate to cross-cultural adjustment.

H1b. There is a positive relationship between metacognitive CQ and (a) general adjustment, (b) interaction adjustment, and (c) work adjustment.

As the evidence has shown, Motivational CQ is the most widely reported predictor of cross-cultural adjustment, including general, interactional, and work adjustment (Ang, Rockstuhl, and Tan 2015,:436; Guðmundsdóttir 2015; Subramaniam et al. 2011). As manifested in the level of interest, drive, and energy to adapt cross-culturally (Livermore 2015), motivational CQ is a strong predictor of a leader's performance and adjustment when working in organizations with employees from different cultures. In Templer, Tay, and Chandrasekar's (2006) research, global employees who were more motivated to explore and experience diverse cultures and were more self-confident in adapting to new cultural environments adjusted better to work, life, and social demands in foreign assignments.

H1c. There is a positive relationship between motivational CQ and (a) general adjustment, (b) interaction adjustment, and (c) work adjustment

Behavioral CQ is considered a predictor of an employee's peer-rated interactional adjustment (Van Dyne, Ang, and Koh 2008). One of the four categories that can create barriers to a team's ultimate success is direct versus indirect communication, trouble with accents and fluency; differing attitudes toward hierarchy and authority; and conflicting decision-making norms (Brett, Behfar, and Kern 2009:90). Since behavioral CQ is the ability to perform appropriate verbal and non-verbal behavior, it is expected that this dimension of CQ will affect the cross-cultural adjustment of foreign employers in different cultural environments. Accordingly, Subramaniam, Ramalu, Wei, and Rose (2011) found that behavioral CQ was correlated positively with all three dimensions of CCA (general adjustment, interaction adjustment, and work adjustment).

H1d. There is a positive relationship between behavioral CQ and (a) general adjustment, (b) interaction adjustment, and (c) work adjustment. 
V. Hajrullahu - H. Tutar - A. Fejza 13/3 (2021) 2440-2454

\section{METHODOLOGY AND PROCEDURES}

\section{Participants and Sampling}

A sample of 181 foreign employees working in Kosovo was used for this study. The data were collected during December 2019. The empirical data comes from a survey of foreign employees living in Kosovo and working in private businesses, from thirteen types (sectors) of institutions, including private schools, private hospitals, marketing companies, private universities, pharmacies, banks, air travel, energy, trade, catering, hotel management, consultancy, and insurance businesses. We either forwarded the link to the online English version of the survey or sent the paper version to foreign employees. From a total of 210 attempted respondents, 181 questionnaires were completed.

\section{Data collection and Instruments}

The research data were collected from foreign national employees working in private enterprises in Kosovo between 05-25 December 2019. In order to apply the questionnaire prepared in line with the purpose of the research, permission was obtained first. Participants were asked to answer the questionnaire form voluntarily for data collection. The opinions of the participants were collected through face-to-face interviews. In total, after missing and incorrect encodings are distinguished. The statements in all scales were created to be answered in Likert format. The Cultural Intelligence Scale developed by Ang colleagues (Ang et al., ( 2007) and the Intercultural Adaptation Scale developed by Black and Stephens (1989) were used to collect data in the study.

\section{Validity and Reliability of Research}

The reliability and internal consistency scales were measured through Cronbach's Alpha. The internal consistency of all the scales and subscales was measured, and Cronbach's alpha values ranged from 0.76 up to 0.90 , indicating highly reliable scales with good internal consistency. Previous studies tested instrument validity (see: Dyne et al., 2008; Tutar and Erdem, 2020; Black Stephens, 1989). The Cronbach alpha of the CQ and CCA in other studies which used the instruments like the study of Gudmundsdottir et al. (2015) was from .91 for the CQS and .89 for CCA.

\section{Statistical analysis}

To visualize the sample's demographic characteristics effectively, we used frequency distribution tables of the demographic data. Descriptive statistics, including the Mean and Standard Deviation of all scales and subscales, were found (Tutar and Erdem, 2020). Correlation coefficients, and their respective statistical significance, were found for all combinations of correlations between all the scales and subscales. Finally, we performed the primary analysis, a hierarchical linear regression model to find the adjusted regression coefficients of each variable in three steps of adding variables, starting with main demographics (Step 1), then with additional demographical questions (Step 2), and finally with the subscales of the Cultural Intelligence (Step 3). Hierarchical Regression Models were carried out for all three Cultural Adjustment subscales: General Adjustment, Work Adjustment, and Interaction Adjustment. The data were analyzed using IBM SPSS Statistics for Windows, Version 21.0. (IBM Corp., Armonk, N.Y., USA).

\section{FINDINGS}

\section{Demographical Characteristics}

The employees of foreign origin sampled in Kosovo were from USA (26\%), Turkey (24.3\%), Albania (14.9\%), Macedonia (11.6\%), Serbia (4.4\%), UK (3.3\%), Austria (2.2\%), Montenegro (1.1\%), Slovenia (1.1\%), and Bulgaria (1.1\%) Netherlands (1.1\%), Ireland (1.1\%), Germany (1.1\%), Switzerland (1.1\%), Korea $(1.1 \%)$, Finland (1.1\%), and other countries (3.6\%). $41.4 \%$ of the foreign employees had managerial positions; $25.4 \%$ had worked in Kosovo for less than a year, $47.5 \%$ had worked for 1 to 5 years, $9.4 \%$ had worked for 6 to 10 years, and $17.1 \%$ had worked for more than ten years. The age distribution followed a normal distribution with $12.2 \%$ of $18-24-$ year-olds, $40.9 \%$ of $25-34$-year-olds, $24.3 \%$ of $35-44$-year-olds, $13.3 \%$ of $45-54$-year-olds, and $9.4 \%$ of 55 years 


\section{Hajrullahu - H. Tutar - A. Fejza 13/3 (2021) 2440-2454}

old and above. Regarding educational status: $13.3 \%$ of the foreign employees had a PhD. $35.4 \%$ had a Master's Degree, $41.4 \%$ had a Bachelor's Degree, and 5.5\% High School. 48.1\% of the foreign employees were male; $56.4 \%$ were married; $51.9 \%$ worked in another foreign country before; $41.4 \%$ had their family with them; $52.5 \%$ had training about the job in Kosovo before coming to Kosovo; $82.3 \%$ had information about the culture of Kosovo before moving. These demographical characteristics were used as adjusting variables in the final regression models.

\section{Descriptive Statistics}

Given that, the scales and the subscales were all measures with the same categorical range of values (1 through 7 ), their means can be compared. The means of all the scales and subscales in descending order are motivational cultural intelligence (5.76), work adjustment (5.73), metacognitive cultural intelligence (5.64), cross-cultural adjustment (5.32), cultural intelligence (5.25), general adjustment (5.20), interaction adjustment (5.20), behavioral cultural intelligence (5.14), and cognitive, cultural intelligence (4.65) (Table 1).

\section{A measurement model and hypothesis testing}

\section{Correlations within and between scales}

Correlation coefficients were calculated for each combination of scales and subscales, and all the scales and subscales were positively correlated and highly statistically significant $(\mathrm{p}<0.01)$ (Table 1$)$. It is worth mentioning specifically (since it is part of Hypothesis 1 ) that a positive correlation was found between cultural intelligence and cross-cultural adjustment (Coeff $=0.53, \mathrm{p}>0.01$ ).

Table 1. Descriptive statistics, reliability coefficients, and correlations $(\mathrm{N}=181)$.

\begin{tabular}{|c|c|c|c|c|c|c|c|c|c|c|c|}
\hline Scale & $\begin{array}{c}\text { Alph } \\
\text { a }\end{array}$ & Mean & SD & 1 & 2 & 3 & 4 & 5 & 6 & 7 & 8 \\
\hline 1. CQ & 0.90 & 5.25 & 0.82 & & & & & & & & \\
\hline 2. MetacognitiveCQ & 0.85 & 5.64 & 1.03 & $.79^{* * *}$ & & & & & & & \\
\hline 3. CognitiveCQ & 0.84 & 4.65 & 1.11 & $.77^{* *}$ & $.52^{* *}$ & & & & & & \\
\hline 4. MotivationalCQ & 0.83 & 5.76 & 0.93 & $.79^{* *}$ & $.62^{* *}$ & $.46^{* *}$ & & & & & \\
\hline 5. BehaviourallCQ & 0.86 & 5.14 & 1.23 & $.71^{* *}$ & $.43^{* *}$ & $.27^{* *}$ & $.44^{* *}$ & & & & \\
\hline 6. CCA & 0.89 & 5.32 & 0.87 & $.52^{* *}$ & $.35^{* *}$ & $.42^{* *}$ & $.52^{* *}$ & $.30^{* *}$ & & & \\
\hline 7. GeneralAdj & 0.82 & 5.20 & 0.97 & $.39^{* * *}$ & $.23^{* *}$ & $.33^{* *}$ & $.41^{* *}$ & $.21^{* *}$ & $.86^{* *}$ & & \\
\hline 8. InteractionAdj & 0.76 & 5.20 & 1.23 & $.50^{* *}$ & $.34^{* *}$ & $.44^{* *}$ & $.46^{* *}$ & $.29^{* *}$ & $.82^{* *}$ & $.48^{* *}$ & \\
\hline 9. WorkAdj & 0.88 & 5.73 & 1.05 & $.39^{* *}$ & $.33^{* *}$ & $.23^{* *}$ & $.42^{* *}$ & $.26^{* *}$ & $.72^{* *}$ & $.43^{* *}$ & $.56^{* *}$ \\
\hline
\end{tabular}

\section{Regression analyses}

Hierarchical regression models which were carried out for all three cultural adjustment subscales (general adjustment (Table 2), work adjustment (Table 3), and interaction adjustment (Table 4)) mostly showed a statistically non-significant effect of demographic variables on the cultural adjustment subscales and statistically significant effect of cultural intelligence. For the general adjustment subscale, none of the main demographical characteristics had a statistically significant association (Table 2, Step 1). The other countryrelated variables also did not significantly affect general adjustment (Table 2, Step 2). Once the cultural intelligence subscales were added to the model, they increased its explanatory power from $4.4 \%$ (R-squared $=0.044)$ to $25.5 \%$ (R-squared $=0.255)$. The cultural intelligence subscale which had the most significant association with general adjustment was motivational CQ $(\mathrm{p}<0.001)$, which affected general adjustment in a positive way (Coeff $=4.18)$, and then the second most significant association was with cognitive $C Q(p=0.031)$, which also had a positive effect (coefficient 2.170) among general adjustment. Two of the four cultural intelligence subscales did not turn out to be significantly associated with general adjustment, namely metacognitive CQ ( $\mathrm{p}=0.327)$ and behavioral CQ ( $\mathrm{p}=0.391)$ (Table 2, Step 3).

Table 2. General Adjustment Hierarchical Regression Model 
V. Hajrullahu - H. Tutar - A. Fejza 13/3 (2021) 2440-2454

\begin{tabular}{|c|c|c|c|c|c|c|}
\hline & \multicolumn{2}{|c|}{ (Step 1) } & \multicolumn{2}{|c|}{ (Step 2) } & \multicolumn{2}{|c|}{ (Step 3) } \\
\hline & Coeff. & p-value & Coeffi. & $\mathrm{p}$-value & Coeff. & $\mathrm{p}$-value \\
\hline Managerial Position & .107 & .176 & .108 & .198 & .667 & .506 \\
\hline Sex & .009 & .909 & .002 & .984 & -.147 & .883 \\
\hline Age & .005 & .950 & .031 & .740 & -.096 & .924 \\
\hline Marital status & -.116 & .182 & -.127 & .191 & -1.341 & .182 \\
\hline Educational status & -.087 & .254 & -.071 & .373 & -.999 & .319 \\
\hline Previous work in a foreign country & & & -.089 & .272 & -1.166 & .245 \\
\hline Working length in Kosovo & & & -.034 & .699 & -.766 & .445 \\
\hline $\begin{array}{l}\text { Living together with the family in } \\
\text { Kosovo }\end{array}$ & & & .049 & .571 & 1.194 & .234 \\
\hline Prior training about the job in Kosovo & & & -.039 & .617 & -.714 & .476 \\
\hline Prior information about Kosovo culture & & & -.039 & .618 & -1.015 & .312 \\
\hline Metacognitive CQ & & & & & -.984 & .327 \\
\hline Cognitive CQ & & & & & 2.170 & .031 \\
\hline Motivational CQ & & & & & 4.181 & .000 \\
\hline Behavioral CQ & & & & & .860 & .391 \\
\hline R-squared & & .030 & & .044 & & .255 \\
\hline
\end{tabular}

None of the main demographical characteristics had a statistically significant association (Table 3, Step 1). The other country-related variables also did not significantly affect interaction adjustment (Table 3, Step 2), except for working length in Kosovo ( $\mathrm{p}=0.007$ ). Once the cultural intelligence subscales were added to the model, they increased its explanatory power considerably, from $29.7 \%$ (R-squared $=0.297$ ) to $59.4 \%$ (R-squared $=$ 0.594). The cultural intelligence subscales which had a significant association with interaction adjustment were motivational CQ $(\mathrm{p}<0.001)$, which had a positive effect (coeff. 0.314$)$ between interaction adjustment, and cognitive CQ also $(\mathrm{p}<0.001)$ had a positive effect (coeff. 0.284$)$ among it. The other two subscales of cultural intelligence were not significantly associated with interaction adjustment - metacognitive CQ $(p=0.473)$ and behavioral CQ ( $\mathrm{p}=0.152)$ (Table 3, Step 3).

Table 3. Interaction Adjustment Hierarchical Regression Model

\begin{tabular}{|c|c|c|c|c|c|c|}
\hline & \multicolumn{2}{|c|}{ (Step 1) } & \multicolumn{2}{|c|}{ (Step 2) } & \multicolumn{2}{|c|}{ (Step 3) } \\
\hline & Coeff. & $\mathrm{p}$-value & Coeffi. & p-value & Coeff. & $\mathrm{p}$-value \\
\hline Managerial Position & .103 & .192 & .035 & .667 & -.038 & .593 \\
\hline Sex & .110 & .173 & .112 & .161 & .101 & .141 \\
\hline Age & .139 & . 105 & .053 & .562 & .016 & .843 \\
\hline Marital status & -.066 & .450 & -.085 & .372 & -0.072 & .382 \\
\hline Educational status & .047 & .537 & .047 & .549 & .044 & .514 \\
\hline $\begin{array}{l}\text { Previous work in a foreign } \\
\text { country }\end{array}$ & & & -.011 & .888 & -0.009 & .898 \\
\hline Working length in Kosovo & & & .233 & .007 & .201 & .007 \\
\hline $\begin{array}{l}\text { Living together with the } \\
\text { family in Kosovo }\end{array}$ & & & .018 & .835 & 0.060 & .424 \\
\hline $\begin{array}{l}\text { Prior training about the job } \\
\text { in Kosovo }\end{array}$ & & & -.104 & .175 & -.123 & .064 \\
\hline $\begin{array}{l}\text { Prior information about } \\
\text { Kosovo culture }\end{array}$ & & & .048 & .524 & 0.019 & .772 \\
\hline Metacognitive CQ & & & & & -.065 & .473 \\
\hline Cognitive CQ & & & & & 0.284 & .000 \\
\hline Motivational CQ & & & & & 0.314 & .000 \\
\hline Behavioral CQ & & & & & .110 & .152 \\
\hline R-squared & & .188 & & 0.297 & & 0.594 \\
\hline
\end{tabular}




\section{Hajrullahu - H. Tutar - A. Fejza 13/3 (2021) 2440-2454}

For the work adjustment regression, the results were partly different. In the first step with demographical variables, the managerial position had a significant association with work adjustment $(p=0.01)$, while the rest of the demographical variables (sex, age, marital status, and educational status) did not (Table 4, Step 1). In the second step of the model, where the country-related variables were added, one additional variable (working length in Kosovo) was significantly associated with work adjustment $(\mathrm{p}=0.047)$ and had a positive effect (coeff. .169). The rest of the country-related variables (previous work in a foreign country, living together with the family in Kosovo, prior training about Kosovo's job, prior information about Kosovo culture) were not significantly associated with work adjustment (Table 4, Step 2). Once the Cultural Intelligence subscales were added to the model, they increased its explanatory power from $33 \%$ (R-squared $=0.33$ ) to $51.9 \%$ ( $R$ squared $=0.519)$. The only cultural intelligence subscale which had a significant association with work adjustment was motivational CQ $(\mathrm{p}<0.001)$, which had a positive effect (coeff. .333), while metacognitive CQ $(p=0.660)$, cognitive CQ $(p=0.909)$, and behavioral CQ $(p=0.228)$ were not significantly associated with work Adjustment. (Table 4, Step 3).

Table 4. Work Adjustment Hierarchical Regression Model

\begin{tabular}{|c|c|c|c|c|c|c|}
\hline & \multicolumn{2}{|c|}{ (Step 1) } & \multicolumn{2}{|c|}{ (Step 2) } & \multicolumn{2}{|c|}{ (Step 3) } \\
\hline & Coeff. & p-value & Coeffi. & p-value & Coeff. & $\mathrm{p}$-value \\
\hline Managerial Position & .202 & .010 & .161 & .048 & .126 & .093 \\
\hline Sex & -.009 & .912 & .001 & .990 & -.010 & .896 \\
\hline Age & .092 & .273 & .019 & .834 & -.008 & .922 \\
\hline Marital status & .026 & .755 & .055 & .561 & .040 & 649 \\
\hline Educational status & .073 & .331 & .072 & .347 & .052 & .464 \\
\hline Previous work in a foreign country & & & .000 & .997 & -.003 & .968 \\
\hline Working length in Kosovo & & & .169 & .047 & .142 & .069 \\
\hline $\begin{array}{l}\text { Living together with the family in } \\
\text { Kosovo }\end{array}$ & & & -.071 & .398 & .001 & .993 \\
\hline Prior training about the job in Kosovo & & & -.100 & .186 & -.106 & .130 \\
\hline Prior information about Kosovo culture & & & .019 & .799 & -.017 & .805 \\
\hline Metacognitive CQ & & & & & .042 & .660 \\
\hline Cognitive CQ & & & & & -.009 & .909 \\
\hline Motivational CQ & & & & & .333 & .000 \\
\hline Behavioral CQ & & & & & .098 & .228 \\
\hline R-squared & & 0.271 & & .330 & & .519 \\
\hline
\end{tabular}

\section{DISCUSSION}

This study aimed to investigate the relationship between cultural intelligence and cross-cultural adjustment of foreign employees working for private businesses in Kosovo and the effect of their cultural intelligence on cross-cultural adjustment. The high correlation coefficients and the hierarchical regression analysis support the hypothesis (H1) that the three subscales of cross-cultural adjustment are positively related to cultural intelligence and all components of cultural intelligence, including metacognitive $C Q$, cognitive $C Q$, motivational CQ, and behavioral CQ. All the cross-cultural adjustment subscales are positively associated with motivational CQ.

Hypothesis 1a is partially supported. While there was a significant positive relationship between cognitive CQ and general adjustment and a positive relationship between cognitive CQ and interaction adjustment, no significant relationship between cognitive CQ and work adjustment was found. Those findings align with the previous research by Guðmundsdóttir (2015) and are partly in line with Ramalu et al., (2011) study. Overall, our results showed the importance of cultural knowledge in Kosovo employees' general and interaction adjustment. Cognitive CQ has been defined as knowledge and understanding about culture, such as the importance in business, but we did not observe a significant relationship between work adjustment and cognitive CQ. One explanation could be that knowing the importance of culture in working or doing business is not enough to enhance work responsibilities in culturally different environments. 


\section{Hajrullahu - H. Tutar - A. Fejza 13/3 (2021) 2440-2454}

One important thing to consider about work adjustment is that in the first step with demographic variables, the managerial position is significantly associated with work adjustment. In the second step of the analysis, the length of time working in Kosovo was another variable that we found to significantly associate with work adjustment $(\mathrm{p}=0.018)$. One explanation for this could be that those working for a considerable period would be more exposed to the culture and be more adept at understanding and coping with cultural differences. Length of time also affected expatriates' cross-cultural adjustment in the Middle East (Setti et al., 2020). These findings suggest that it takes time for an employee to adjust to working in the context of Kosovo. Therefore, for an employee to perform better, employers must wait to become more accustomed to cultural differences and develop coping strategies for better adjustment to work. Further studies should examine the effect of working length in a foreign culture, such as investigating the main factors that change with time and allow successful adjustment to a new environment. Another critical area of investigation is the functional role's effect, as our results show that a managerial position affects adjustment to working in Kosovo.

Our findings do not support hypothesis $1 \mathrm{~b}$. No statistically significant relationship was found between metacognitive CQ and general adjustment, interaction adjustment, and work adjustment. This is in line with the findings of a study by Huff et al. (2014). However, this was based on adjusted models (adjusted for demographical and country-related characteristics), while we found a significant relationship in the unadjusted correlations table. Adjusting variables like demographics, which included sex, age, marital status, and other variables like educational status, previous work in a foreign country, living together with the family in Kosovo, prior training about the job in Kosovo, and prior information about Kosovo culture had a considerable effect on the relationship we observed between metacognitive CQ and cross-cultural adjustment. Organizations should pay attention to those characteristics by training employees, giving them information about the culture before sending them to the new assignment and considering sending them together with their families. In the same way, employees should attempt to gather information about the country's culture in which they will work.

The data fully support hypothesis 1c. Motivational CQ has a statistically significant positive relationship with all the Cross-Cultural Adjustment components (general adjustment, interaction adjustment, and work adjustment). These findings are consistent with previous studies (Guðmundsdóttir 2015; Ramalu et al. 2011; Templer et al. 2006; Shu, McAbee, and Ayman, 2017; Jyoti and Kour 2015; Huff, Song, and Gresch 2014; Setti et al., 2020). Since motivational CQ is the motivation or drive and energy to adapt to culturally different environments (Livermore 2015, p.26), it was expected that it should have a considerable effect on cross-cultural adjustment. In the context of this study, motivation is a significant factor to consider when working with people from different cultural backgrounds. It can be suggested that it is in a person's interest to understand better their motivation for engaging in culturally different environments. Employers and managers should also be sure about the motivation that an employee has to engage with different cultures, preventing high turnover, as shown in the study by Akhal and Liu (2019). A high motivational CQ should be a criterion for selecting candidates when assigning them for international work.

Hypothesis $1 \mathrm{~d}$ is not supported by the findings. We did not observe a statistically significant relationship between behavioral CQ and General Adjustment, Interaction Adjustment, and Work Adjustment. These results are the same as the result of a study made by Jyoti and Kour (2015) and the study's results (Huff et al., (2014).

The findings of this study can be discussed from Social Learning Perspective. The theory implies the environmental causes of an individual's behavior and its impact (Black and Mendenhall, 1991; Auf der Heide, 2007) on cross-cultural adjustment. It can be said that cross-cultural adjustment of foreign employees in Kosovo is a process in which as the results demonstrated many factors like demographics, which included sex, age, marital status, and other variables like educational status, previous work in a foreign country, living together with the family in Kosovo, prior training about the job in Kosovo, and prior information about Kosovo culture and length of time working in Kosovo, were very important in enhancing it. Moreover, the most critical foreign employee's cultural intelligence affected this process by improving cross-cultural living and working 
conditions. As a result, it is essential to provide training and other modalities that would enhance employees' CQ because, as the study of Okpara et al. (2020) pointed out, training had significant and positive influences on expatriates' adjustment. An employer with high levels of CQ can help leaders recognize their leaders' transformational behaviors and enhance employees' job performance (Nam \& Park, 2019) which should be very important for the cross-cultural adjustment of foreign employees. Moreover, in a study made by Tsegaye et al. (2019), it was found that a cross-cultural adjustment level mediates innovative behavior, which in turn is a vital skill for employees that especially the private sector in Kosovo needs.

\section{Limitations and future directions}

One of this study's limitations is that all of the data were collected through a self-reported questionnaire. This could lead to self-reporting bias, as demonstrated in Podsakoff and Organ's (1986) study (Podsakoff, Mackenzie, and Podsakoff 2011). Future research should include information from other sources like superiors and peers, and so on. The second limitation is the language of the questionnaire. This was in English, which could also open the possibility of misunderstanding the questions, where English was not the respondent's native language.

Another limitation of our study was the sample size. As there was no available list of foreign workers in Kosovo, the exact number of the workers could not be ascertained, and not all workers could be contacted. To address this limitation, we contacted the ministry of trade and finance, the ministry of internal affairs, and the chamber of commerce and tried to take as many contacts as possible.

\section{CONCLUSION}

This study emphasizes the importance of cultural intelligence as a skill that enhances employees' crosscultural adjustment, in this case, in Kosovo. We observed an effect on adjustment to working in Kosovo from all aspects of CQ. A person's motivation to work in cross-cultural environments is the main factor that enhances their adjustment to a culturally different context. Employees and employers will produce better outcomes when they maintain high motivation levels for cross-cultural adjustment. Kosovo's private businesses need skilled and competent employees with international experience, allowing more significant learning and improved performance. Foreign employees' ability to adapt quickly to working abroad is related to having higher cultural intelligence and incredibly motivational CQ, which employers consider when sending workers to work for private businesses in Kosovo and employees planning to work in Kosovo. A high level of CQ should be a key criterion for sending employees on international assignments. 


\section{REFERENCES}

Abugre, J. B., Williams, K., \& Debrah, Y. A. (2020). Dimensions of expatriates adjustment in distant subsidiaries: A field study of a sub-Saharan African institutional distance. Thunderbird International Business Review, 62(4), 371-384. https://doi.org/10.1002/tie.22105

Akhal, K., \& Liu, S. (2019). Cultural intelligence effects on expatriates' adjustment and turnover intentions in Mainland China. Management Research Review, 42(7), 818-836. https://doi.org/10.1108/MRR-04-2018-0157

Anderson, L. E. (1994). A new look at an old construct: Cross-cultural adaptation. International Journal of Intercultural Relations, 18(3), 293-328. https://doi.org/10.1016/0147-1767(94)90035-3

Andreatta, S., \& Ferraro, G. (2012). Elements of culture: An applied perspective. Nelson Education.

Ang, S., Rockstuhl, T., \& Tan, M. L. (2015). Cultural Intelligence and Competencies. In International Encyclopedia of the Social \& Behavioral Sciences (2nd edition, Vol. 5, pp. 433-439). Elsevier Ltd. https://doi.org/10.1016/B978-0-08-097086-8.25050-2

Ang, S., Van Dyne, L., Koh, C., Ng, K. Y., Templer, K. J., Tay, C., \& Chandrasekar, N. A. (2007). Cultural Intelligence: Its Measurement and Effects on Cultural Judgment and Decision Making, Cultural Adaptation and Task Performance. Management and Organization Review, 3(3), 335-371. https://doi.org/10.1111/j.1740-8784.2007.00082.x

Auf der Heide, L. (2007). Social Learning Theory. In The Blackwell Encyclopedia of Sociology. John Wiley \& Sons, Ltd. https://doi.org/10.1002/9781405165518.wbeoss157

Bandura, A. (1977). Social Learning Theory. PRENTICE HALL, Englewood Cliffs, New Jersey.

Black, J. S. (1988). Work Role Transitions: A Study of American Expatriate Managers in Japan. Journal of International Business Studies, 19(2), 277-294. https://doi.org/10.1057/palgrave.jibs.8490383

Black, J. S. (1990). The Relationship of Personal Characteristics with the Adjustment of Japanese Expatriates. Management International Review, 30(2), 119-134. https://www.jstor.org/stable/40228014

Black, J. S., \& Mendenhall, M. (1991). The U-Curve Adjustment Hypothesis Revisited: A Review and Theoretical Framework. In Source: Journal of International Business Studies (Vol. 22, Issue 2). https://about.jstor.org/terms

Black, J. S., \& Stephens, G. K. (1989). The Influence of the Spouse on American Expatriate Adjustment and Intent to Stay in Pacific Rim Overseas Assignments. Journal of Management, 15(4), 529-544. https://doi.org/10.1177/014920638901500403

Brett, J., Behfar, K., \& Kern, M. C. (2009). Managing Multicultural Teams. The Essential Guide to Leadership. https://www.researchgate.net/publication/6666162

Brislin, R., Worthley, R., \& Macnab, B. (2006). Cultural intelligence: Understanding behaviors that serve people's goals. Group and Organization Management, 31(1), 40-55. https://doi.org/10.1177/1059601105275262

Cojocaru, A. (2017). Kosovo Jobs Diagnostic. In Kosovo Jobs Diagnostic. World Bank. https://doi.org/10.1596/27173

Dyne, L. Van, Ang, S., \& Koh, C. (2008). Development and Validation of the CQS: The Cultural Intelligence Scale. In S. Ang \& L. Van Dyne (Eds.), Handbook of Cultural Intelligence (1. st edition, pp. 16-38). ME Sharpe. https://culturalq.com/wp-content/uploads/2019/03/Van-Dyne_Ang_Koh-Handbook-Ch-2-CQSScale.pdf

Earley, P. C. (2002). Redefining interactions across cultures and organizations: Moving forward with cultural intelligence. Research in Organizational Behavior, 24, 271-299. https://doi.org/10.1016/S0191-3085(02)240083

Group, W. B. (2017). Western Balkans. World Bank, Vienna. https://openknowledge.worldbank.org/handle/10986/28316

Gudmundsdottir, S. (2015). Nordic expatriates in the US: The relationship between cultural intelligence and adjustment. International Journal of Intercultural Relations, 47, 175-186. https://doi.org/10.1016/j.ijintrel.2015.05.001 


\section{Hajrullahu - H. Tutar - A. Fejza 13/3 (2021) 2440-2454}

Guðmundsdóttir, S. (2015). Nordic expatriates in the US: The relationship between cultural intelligence and adjustment. International Journal of Intercultural Relations, 47, 175-186. https://doi.org/10.1016/j.ijintrel.2015.05.001

Handjiski, B., Lucas, R., Selen, P. M., \& Guerin, S. (2010). Enhancing Regional Trade Integration in Southeast Europe. The International Bank for Reconstruction and Development/The World Bank 1818 H Street, N.W. https://doi.org/10.1596/978-0-8213-8259-2

Hofstede, G., Hofstede, G. J., \& Minkov, M. (2010). Cultures and Organizations. Mc Graw Hill.

House, R. J., Hanges, P. J., Javidan, M., Dorfman, P. W., \& Gupta, V. (2004). Culture, leadership, and organizations: The GLOBE study of 62 societies. In Sage Publications, Inc. (4.). Sage Publications. https://doi.org/10.1017/CBO9781107415324.004

Hu, S., Liu, H., Zhang, S., \& Wang, G. (2019). Proactive personality and cross-cultural adjustment: Roles of social media usage and cultural intelligence. https://doi.org/10.1016/j.ijintrel.2019.10.002

Huff, K. C., Song, P., \& Gresch, E. B. (2014a). Cultural intelligence, personality, and cross-cultural adjustment: A study of expatriates in Japan. International Journal of Intercultural Relations, 38(1), 151-157. https://doi.org/10.1016/j.ijintrel.2013.08.005

Huff, K. C., Song, P., \& Gresch, E. B. (2014b). Cultural intelligence, personality, and cross-cultural adjustment: A study of expatriates in Japan. International Journal of Intercultural Relations, 38(1), 151-157. https://doi.org/10.1016/j.ijintrel.2013.08.005

Jyoti, J., \& Kour, S. (2015). Assessing the cultural intelligence and task performance equation Mediating role of cultural adjustment. Cross-Cultural Management, 22(2), 236-258. https://doi.org/10.1108/CCM-04-20130072

Kirkman, B. L., \& Chen, G. (2006). Cultural Intelligence and International Assignment Effectiveness. Academy of Management Proceedings, 2006(1), C1-C6. https://doi.org/10.5465/ambpp.2006.27162843

Kryeziu, L., \& Coşkun, R. (2018). Political and Economic Institutions and Economic Performance: Evidence from Kosovo. southeast European Journal of Economics and Business, 13(2), 84-99. https://doi.org/10.2478/jeb-2018-0013

Lee, L.-Y., Veasna, S., \& Wu, W.-Y. (2013). The effects of social support and transformational leadership on expatriate adjustment and performance moderating roles of socialization experience and cultural intelligence. Career Development International, 18(4), 377-415. http://10.0.4.84/CDI-06-2012-0062

Li, M. (2020). An examination of two major constructs of cross-cultural competence: Cultural intelligence and intercultural competence. Personality and Individual Differences, 164(May), 110105. https://doi.org/10.1016/j.paid.2020.110105

Lin, Y.-C. chun, Shin-Yih Chen, A., Song, Y.-C. chen, Chen, A. S. yih, \& Song, Y.-C. Chen. (2012). Does your intelligence help to survive in a foreign jungle? The effects of cultural intelligence and emotional intelligence on cross-cultural adjustment. International Journal of Intercultural Relations, 36(4), 541-552. https://doi.org/10.1016/j.jintrel.2012.03.001

Livermore, D. (2011). The cultural intelligence difference: master the one skill you can't do without in today's global economy. American Management Association. https://books.google.com/books/about/The_Cultural_Intelligence_Difference_Spe.html?id=cQAsPwO_ $2 \mathrm{mcC}$

Livermore, D. (2015). Leading With Cultural Intelligence: The Real Secret to Success (2nd edition). AMACOM. www.amanet.org

Miller, G., \& Shaffer, M. (2008). Cultural Intelligence : A Key Success Factor for Expatriates. In S. Ang \& L. Van Dyne (Eds.), Handbook of Cultural Intelligence Theory, Measurement, and Applications (Issue January 2008, pp. 107-125). M.E. Sharpe, Inc.

Mosakowski, E., \& Earley, P. C. (2004). Cultural Intelligence. Harvard Business Review, 82(October), 139-146. https://doi.org/10.111/jocn.

Nam, K., \& Park, S. (2019). Factors Influencing Job Performance: Organizational Learning Culture, Cultural Intelligence, and Transformational Leadership. Performance Improvement Quarterly, 32(2), 137-158. https://doi.org/10.1002/piq.21292 


\section{Hajrullahu - H. Tutar - A. Fejza 13/3 (2021) 2440-2454}

Nunes, I. M., Felix, B., \& Prates, L. A. (2017). Cultural intelligence, cross-cultural adaptation and expatriate performance: a study with expatriates living in Brazil. Revista de Administração, 52(3), 219-232. https://doi.org/10.1016/j.rausp.2017.05.010

Okpara, J. O., Kabongo, J. D., \& Lau, W. K. (2020). Effects of pre-departure and post-arrival cross-cultural training on expatriates adjustment: A study of Chinese expatriates in Nigeria. Thunderbird International Business Review, 2019, 1-16. https://doi.org/10.1002/tie.22185

Podsakoff, P. M., Mackenzie, S. B., \& Podsakoff, N. P. (2011). Sources of Method Bias in Social Science Research and Recommendations on How to Control It. https://doi.org/10.1146/annurev-psych-120710-100452

Polák-Weldon, R., Balogh, Á., Bogdány, E., \& Cizmadia, T. (2012). The challenges of globalization: The changing role of cultural intelligence in the 21st century. Knowledge and Learning: Global Empowerment (Make Learn) Proceedings of the Management, Knowledge and Learning International Conference, 353-361. https://www.issbs.si/press/ISBN/978-961-6813-10-5/papers/ML12_081.pdf

Ravasi, C., Salamin, X., \& Davoine, E. (2015). Cross-cultural adjustment of skilled migrants in a multicultural and multilingual environment: an explorative study of foreign employees and their spouses in the Swiss context. International Journal of Human Resource Management, 26(10), 1335-1359. https://doi.org/10.1080/09585192.2014.985328

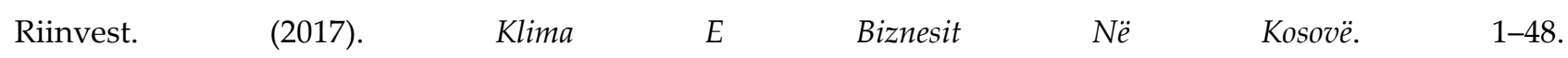
https://www.riinvestinstitute.org/uploads/files/2017/May/19/Klima_e_Biznesit1495199071.pdf

Searle, W. (1990). The prediction of psychological and sociocultural adjustment during cross-cultural transitions. North, 14, 449-464.

Setti, I., Sommovigo, V., \& Argentero, P. (2020). Enhancing expatriates' assignments success: the relationships between cultural intelligence, cross-cultural adaptation, and performance. Current Psychology. https://doi.org/10.1007/s12144-020-00931-w

Sharma, N., \& Hussain, D. (2017). Current Status and Future Directions for Cultural Intelligence. Journal of Intercultural Communication Research, 46(1), 96-110. https://doi.org/10.1080/17475759.2016.1264444

Shkodra, N., Xhemili, N., \& Myrvete, B.-P. (2015). Challenges and Problems in the Kosovo Reality Related to Foreign Direct Investment. ILIRIA International Review, 5(1), 81. https://doi.org/10.21113/iir.v5i1.6

Shu, F., McAbee, S. T., \& Ayman, R. (2017). The HEXACO personality traits, cultural intelligence, and international student adjustment. Personality and Individual Differences, 106, 21-25. https://doi.org/10.1016/j.paid.2016.10.024

Sotshangane, N. (2005). What Impact Globalization has on Cultural Diversity? Alternatives : Turkish Journal Of International Relations, 1(4). https://doi.org/10.21599/atjir.95106

Sternberg, R. J. (2008). Successful intelligence as a framework for understanding cultural adaptation. In S. Ang \& L. Van Dyne (Eds.), Handbook of Cultural Intelligence - Theory, Measurement and Application (pp. 306-317). M.E. Sharpe, Inc. https://books.google.com/books?hl=en\&lr=\&id=mKBsBgAAQBAJ\&oi=fnd\&pg=PA306\&dq=Successful+I ntelligence+as+a+Framework+for+Understanding+Cultural+Adaptation\&ots=YEvDoRiewz\&sig=3FdSs 3F8tG8iVR4tFAQDPFXHCpA

Subramaniam, A. L., Ramalu, S., Wei, C. C., \& Rose, R. C. (2011). The Effects of Cultural Intelligence on CrossCultural Adjustment and Job Performance amongst Expatriates in Malaysia. International Journal of Business and Social Sciences, 2(9), 59-72. https://doi.org/10.1021/cg1011023

Templer, K. J., Tay, C., \& Chandrasekar, N. A. (2006). Motivational cultural intelligence, realistic job preview, realistic living conditions preview, and cross-cultural adjustment. In Group and Organization Management (Vol. 31, Issue 1, pp. 154-173). https://doi.org/10.1177/1059601105275293

Terziu, H. (2016). National Culture and the Model of Business Organization for the Case of Kosovo. European Journal of Economics and Business Studies, 4(1), 97. https://doi.org/10.26417/ejes.v4i1.p97-106

Thomas, D. C., \& Inkson, K. C. (2009). Cultural Intelligence: Living and Working Globally. In Cultural Intelligence: Living and Working Globally. Berrett-Koehler Publishers, Inc. http://0212592dp.y.http.eds.a.ebscohost.com.proxy.sakarya.deep-

knowledge.net/eds/ebookviewer/ebook/bmxlYmtfXzI2MDc1N19fQU41?sid=b21fd5d6-6989-4f90-863a- 
cc3397ec7433@sessionmgr4007\&vid=4\&format=EB\&rid=9

Thomas, D. C., \& Inkson, K. C. (2017). Cultural Intelligence: Surviving and Thriving in the Global Village. (3d edition). Berrett-Koehler Publishers, Inc. http://0212586sz.y.http.eds.b.ebscohost.com.proxy.sakarya.deepknowledge.net/eds/ebookviewer/ebook/bmxlYmtfXzEzNTYwMTZfX0FO0?sid=bd6f5091-c176-481e8d81-01ccd4e788c4@pdc-v-sessmgr06\&vid=1\&format=EB\&rid=4

Tsegaye, W. K., Su, Q., \& Malik, M. (2019). Expatriate cultural values alignment: The mediating effect of crosscultural adjustment level on innovative behaviour. Creativity and Innovation Management, 28(2), 218-229. https://doi.org/10.1111/caim.12308

Tutar, H., \& Erdem, A. T. (2020). Örnekleriyle Bilimsel Araştırma Yöntemleri ve SPPS Uygulamaları. Ankara: Seçkin Yayıncılık.

Van Dyne, L., Ang, S., \& Koh, C. (2008). Development and Validation of the CQS The Cultural Intelligence Scale. In S. Ang \& L. Van Dyne (Eds.), Handbook of Cultural Intelligence (pp. 16-37). M.E. Sharpe, Inc. All.

Van Dyne, L., Ang, S., Ng, K. Y., Rockstuhl, T., Tan, M. L., \& Koh, C. (2012). Sub-Dimensions of the Four Factor Model of Cultural Intelligence: Expanding the Conceptualization and Measurement of Cultural Intelligence. Social and Personality Psychology Compass, 6(4), 295-313. https://doi.org/10.1111/j.17519004.2012.00429.x

Wu, P.-C., \& Ang, S. H. (2011). The impact of expatriate supporting practices and cultural intelligence on crosscultural adjustment and performance of expatriates in Singapore. The International Journal of Human Resource Management, 22(13), 2683-2702. https://doi.org/10.1080/09585192.2011.599956

Zhang, Y. (2013). Expatriate Development for Cross-Cultural Adjustment: Effects of Cultural Distance and Cultural Intelligence. Human Resource Development Review, 12(2), 177-199. https://doi.org/10.1177/1534484312461637 